(C) 2005 The Journal of Medicine and Philosophy 30(4): 379-394.

\title{
Aquinas's Account of Human Embryogenesis and Recent Interpretations
}

\author{
Jason T. Eberl \\ Indiana University-Purdue University Indianapolis
}

\begin{abstract}
In addressing bioethical issues at the beginning of human life, such as abortion, in vitro fertilization, and embryonic stem cell research, one primary concern regards establishing when a developing human embryo or fetus can be considered a person. Thomas Aquinas argues that an embryo or fetus is not a human person until its body is informed by a rational soul. Aquinas's explicit account of human embryogenesis has been generally rejected by contemporary scholars due to its dependence upon medieval biological data, which has been far surpassed by current scientific research. A number of scholars, however, have attempted to combine Aquinas's basic metaphysical account of human nature with current embryological data to develop a contemporary Thomistic account of a human person's beginning. In this paper, I discuss two recent interpretations in which it is argued that a human person does not begin to exist until a fetus has developed a functioning cerebral cortex.
\end{abstract}

Keywords: Aquinas, person, soul, embryo, Donceel, Pasnau

\section{INTRODUCTION}

In addressing bioethical issues at the beginning of human life, such as abortion, in vitro fertilization, and embryonic stem cell research, one primary concern is to establish when a developing human embryo or fetus can be considered a person; for it is generally held that only persons are the subjects of rights, such as a "right to life." An important metaphysical viewpoint to consider in this regard is that of the $13^{\text {th }}$ century philosopher 
and theologian Thomas Aquinas. Aquinas's understanding of human nature merits serious attention by philosophers and bioethicists for two reasons. First, his overall metaphysical account stakes a middle-ground between Platonic/Cartesian substance dualism, in which a person is identified as an immaterial soul, and reductive physicalism. ${ }^{1}$ Aquinas's account thereby safeguards the virtues of each extreme position while avoiding their respective pitfalls (Eberl, 2004; Stump, 1995). Second, Aquinas is a seminal figure in Roman Catholic thought and his views are informative of the Church's magisterial teaching (John Paul II, 1998; Leo XIII, 1879). A proper understanding of Aquinas's account of human embryogenesis is thus valuable both as part of an overall metaphysical understanding of human nature that has philosophical merit, and as an insight into the foundation of the Roman Catholic position regarding various bioethical issues at the beginning of human life.

Aquinas argues that all human beings are persons (Summa theologiae [ST] IIIa 16.12.ad 1), but that an embryo or fetus is not a human being until its body is informed by a rational soul. Aquinas's explicit account of human embryogenesis has been generally rejected by contemporary scholars due to its dependence upon medieval biological data, which has been far surpassed by current scientific research. Aquinas, following Aristotle, understands conception to involve male semen acting upon female menstrual blood to form an embryo; semen is the agent of conception and the female contribution is simply the matter that passively receives semen's activity to be formed into an embryo (ST Ia 118.1.ad 4; Aristotle, De generatione animalium [DGA] II 3, 736a24-737b6). The contemporary understanding of conception characterizes both the male and female gametes — sperm and ovum instead of semen and menstrual blood - as 
active components insofar as each contribute half the genetic code that serves as the formal and efficient cause of an embryo's formation.

A number of scholars, however, have attempted to combine Aquinas's basic metaphysical account of human nature with current embryological data to develop a contemporary Thomistic account of a human being's beginning. ${ }^{2}$ The issue at hand in developing such an account is the distinction between "immediate"-when fertilization of an ovum by a sperm cell is complete—and "delayed"—-sometime after fertilization— hominization. The term "hominization" refers to when a developing embryo first has a specifically "human" rational soul as its substantial form, i.e., organizing principle. ${ }^{3}$ The debate among scholars who argue for either immediate or delayed hominization centers on the application of Aquinas's metaphysical principle that only an appropriate body may be informed by a rational soul to constitute a human being. Those who favor immediate hominization, such as Benedict Ashley (1976), claim that there is nothing about the biological nature of a human embryo from the moment the process of fertilization is complete that disallows its being informed by a rational soul. This account purports to satisfy the above Thomistic principle while denying Aquinas's own conclusion, based on the embryological data at his disposal, that an early embryo's body is not appropriate for being informed by a rational soul; I will elaborate on Aquinas's principle and conclusion in the following section.

Scholars who favor delayed hominization, such as Joseph Donceel (1970), Robert Pasnau (2002), and Norman Ford (1988), argue that there are certain intrinsic qualities of an early embryo which indicate that it is not an "individual substance of a rational nature" ${ }^{4}$ until it reaches a certain point in its biological development. I have previously 
discussed Ford's interpretation (Eberl, 2000a). In this article, I will consider the interpretations offered by Donceel and Pasnau and show how they fall short of representing the Thomistic position. First, though, it is appropriate to elucidate Aquinas's explicit account of human embryogenesis.

\section{AQUINAS'S ACCOUNT OF EMBRYOGENESIS}

Aquinas's account of human embryogenesis begins with his understanding of a human being as constituted by a rational soul informing a material body (Eberl, 2004). In defining the necessary and sufficient conditions for something to be informed by a soulwhich may be either vegetative, sensitive, or rational ${ }^{5}$ - Aquinas first notes Aristotle's definition of "soul" as "the actuality of a physical organic body having life potentially" (ST Ia 76.4.ad 1; cf. Aristotle, De anima [DA] II 1, 412a20-2). Aquinas then asserts that "such potentiality does not reject the soul" (ST Ia 76.4.ad 1). Aquinas explains this definition and assertion as follows:

It is said that the soul is the actuality of a body, etc., because through the soul it is a body, is organic, and has life potentially. But the first actuality is said to be in potentiality with respect to the second actuality, which is the operation. For such a potentiality does not reject, that is, does not exclude the soul (ST Ia 76.4.ad 1; cf. In Aristotelis librum De anima commentarium [In DA] II 2).

Aquinas holds that a soul's potentiality to perform its definitive operations-whether life, sensation, or rational thought — is necessary for it to exist (Quaestio disputata de anima [QDA] XII.ad 7). The actualization of such potentiality, however, is accidental to the soul's existence: “To be actually thinking or sensing is not substantial being, but accidental" (QDA XII).

Of course, a developing human embryo or fetus, and even a newborn infant, does not actually exercise all the operations proper to a human being, including rational 
activity. Nonetheless, Aquinas denies that this lack implies that a rational soul does not inform the matter of a developing human embryo, fetus, or newborn infant. All that is required for the presence of a rational soul, and thus the existence of a human being, is a human body that has the potentiality for the operations proper to a rational soul:

If a human being derives his species by being rational and having an intellect, whoever is within the human species is rational and has an intellect. But a child, even before leaving the womb, is within the human species; although there are yet no phantasms in it which are actually intelligible (Summa contra Gentiles [SCG] II 59).

Concerning the question of when the potentiality for the operations proper to a rational soul is first present in a developing human body, Aquinas asserts that a body must have the proper organic structure if it is to have a rational soul as its substantial form: "Since the soul is the act of an organic body, before the body has organs in any way whatever, it cannot be receptive of the soul" (Quaestiones disputatae de potentia dei [QDP] III 12). The appropriate organs for a rational soul are those associated with sensation, because it is through sensation of particular things that the mind comes to possess intelligible forms, which are the natures of things understood as abstracted from any particular material conditions (ST Ia 84.6; Eberl, 2004; Stump, 2003, pp. 244-76; Pasnau, 2002, pp. 278-95, 310-29; Kretzmann, 1999, pp. 350-64). The abstraction of intelligible forms from the products of sensation - the "phantasms" referred to in the above passage from SCG-is the essence of rational thought as Aquinas defines it:

"Therefore, the rational soul ought to be united to a body which may be a suitable organ of sensation" (ST Ia 76.5; cf. ST Ia 55.2). This understanding leads Aquinas to develop an account of successive ensoulment in a human embryo's formation. After conception - the action of semen upon menstrual blood - occurs, a material body exists 
that has a vegetative soul as its substantial form, i.e., an entity that has life at its most basic level. As the early embryo develops and its organic structure increases in complexity to the point where it can support sensitive operations, the embryo's vegetative soul is annihilated and its matter is informed by a sensitive soul. Since, according to Aquinas, a thing's identity is determined by its having the same substantial form (Eberl, 2004), the early vegetative embryo has ceased to exist and a new embryo has come into existence that is an animal life form, due to its having the capacity for sensation.

The final stage of embryonic development occurs when the embryo has developed to a point where it has a sufficiently complex organic structure to allow for rational operations. ${ }^{6}$ At this point, the sensitive soul is annihilated and the animal embryo goes out of existence as its matter becomes informed by a rational soul:

And thus it must be said that the vegetative soul is first in the seed, but it is discarded in the generative process and another succeeds it that is not only vegetative but also sensitive, which, having been discarded, again another is added that at the same time is vegetative, sensitive, and rational (QDA XI.ad 1; cf. QDP III 9.ad 9; ST Ia 76.3.ad 3, 118.2.ad 2; SCG II 89; Compendium theologiae [CT] 92; Quaestio disputata de spiritualibus creaturis III.ad 13).

Since Aquinas adopts Boethius's definition of a person as an "individual substance of a rational nature" and all human beings are persons, a developing embryo is neither a person nor a human being until its matter is informed by a rational soul. At this point, one may consider the possibility that a developing embryo - prior to rational ensoulment - is an individual human being, though is not yet a person. In other words, perhaps you existed as the embryos informed by vegetative and sensitive souls prior to your matter being informed by a rational soul. This view, however, conflicts with Aquinas's understanding of what is essential to human nature. First, Aquinas asserts that 
every human being is a person (ST IIIa 16.12.ad 1). Personhood is essential to human nature. Furthermore, Aquinas's interpretation of the Boethian definition of personhood requires, at minimum, the existence of a rational soul that is the substantial form of an appropriate physical body. As Brian Leftow (2001, p. 129) points out, Aquinas does not consider something "human" unless it is, or has been, "part of a whole, ensouled human body." A developing embryo with human DNA is not necessarily, just for that reason, a human being or part of a human being. It is matter informed by a rational soul that fulfills the definition of a human being. Hence, Aquinas's explicit view of human embryogenesis entails that no human being exists prior to the instantiation of a rational soul in the matter of a developing embryo.

The basic metaphysical principle Aquinas employs in his account of embryogenesis is that a rational soul does not inform a material body—resulting in a human being's existence — unless the body is properly disposed for the sake of that type of soul (QDP III 9.ad 6, ad 20; SCG II 89; ST Ia 90.4). The requisite disposition is the body's having sense organs and a brain capable of imagination such that phantasms of sensible objects may be generated for the mind to abstract intelligible forms, which is the nature of rational thought. A body disposed in such a way does not seem to exist until late in gestation after first a vegetative embryo, and then an animal embryo, has existed. Aquinas thus concludes that a living, sensitive, and rational human being does not begin to exist until some point well after conception: ${ }^{7}$

Therefore, it must be said that a rational soul, which at the same time is sensitive and nutritive, is created by $\mathrm{God}^{8}$ at the end of human generation; the pre-existing forms having been corrupted (ST Ia 118.2.ad 2). ${ }^{9}$ 


\section{DONCEEL}

Donceel and Pasnau both contend that a sufficiently organized body, suitable for being informed by a rational soul, does not exist until the cerebral cortex of the embryonic brain is formed. This conclusion is purported to follow from the fact that a functioning cerebral cortex is required for rational thought to occur insofar as (1) it is the organ of a human being's sensitive and imaginative capacities, and (2) cerebral neural activity is correlated with rational activity. ${ }^{10}$ Donceel thus argues,

Man's higher, spiritual [i.e., rational] faculties have no organs of their own, since they are immaterial, intrinsically independent of matter. But they need, as necessary conditions of their activity, the cooperation of the highest sense powers, imagination, memory, what the Scholastics called the "cogitative power." Its activity presupposes that the brain be fully developed, that the cortex be ready. Only then is the stage set for another ontological shift; matter now is highly enough organized to receive the highest substantial form, the spiritual, human soul, created by God (Donceel, 1970, p. 83, emphasis mine).

Donceel refers in this passage to the necessity of neural development for the sake of rational "activity." It is important to recall here that Aquinas, in his account of embryogenesis, never asserts that a fetus must actually think rationally in order for it to be a human being. As noted above, Aquinas contends that only the potentiality for rational thought must be present. Such potentiality is sufficient for a fetus to be informed by a rational soul. Donceel agrees and yet contends that the potentiality for rational thought is present only when a fetus has developed a functioning cerebral cortex: "The least we may ask before admitting the presence of a human soul is the availability of these organs: the senses, the nervous system, the brain, and especially the cortex" (Donceel, 1970, p. 101). We must, therefore, consider carefully Aquinas's notion of 
"potentiality" and how it should be applied to the case at hand of when a human embryo or fetus first has the potentiality for rational thought.

In the passage quoted above from ST Ia 76.4.ad 1 and elsewhere, Aquinas distinguishes between first and second actuality: "First actuality is a thing's form and integrity, and second actuality is its operation" (ST Ia 48.5; cf. In DA II 2; QDP I 1). A first actuality is the active potentiality to perform some operation. The locus of a substance's set of first actualities — or active potentialities — is its substantial form, which, for a human being, is a rational soul. A second actuality is the operation of a first actuality brought about through some additional cause (Quaestiones disputatae de veritate $\mathrm{V}$ 8.ad 10). In contrast to an active potentiality, something has a passive potentiality if it can be the subject of externally directed change such that it can become what it is not already.

In addition to the difference between first and second actuality, it must be noted that first actuality comes in two varieties. The first is what Pasnau (2002, p. 115) refers to as a "capacity in hand" to perform an action, which means that no further development or significant change is required for the potentiality to be actualized. For example, I have, as a first actuality, the capacity to speak Spanish (having majored in it in college along with philosophy). It just happens to be the case at this moment that I am not using this capacity and so it is not in a state of second actuality, which it would be if I were actually speaking Spanish right now. It is apparent that Donceel has this construal of first actuality in mind when he asserts that the potentiality for rational thought is present only after cerebral development. The second is what Norman Kretzmann (1999, p. 39) refers to as a substance's "natural potentiality" to develop a capacity to perform an action. For 
example, before I learned to speak Spanish and thereby developed a capacity in hand to do so, I had a natural potentiality to develop this capacity. I have numerous other natural potentialities, some of which I have developed into capacities in hand, such as my capacity to play chess, and others which I have left undeveloped, such as my potentiality to learn to read Sanskrit.

In applying the concepts of first and second actuality to the presence of a rational soul, Aquinas contends that all that is required for a rational soul to inform the matter of a particular body is that the body has an active potentiality to perform the operations proper to a rational soul — vegetative, sensitive, and rational. The actual performance of these operations is accidental to the soul's existence (QDA XII). Thus, since a rational soul is the substantial form of a human body, the existence of a human body with active potentialities for life, sensation, and rational thought entails the existence of a rational soul informing that body. It is inconsequential whether such operations are actually exercised in a body for a rational soul to inform it: "A soul in first actuality is a soul: a sleeping animal continues to have an actual sensory soul, just not an actually operating sensory soul" (Kretzmann, 1999, p. 379, n. 27; see ST Ia 118.1.ad 4).

With respect to a human embryo, Aquinas asserts, "Just as the soul in an embryo is in act, but imperfectly, so also it operates, but imperfect operations” (QDA XI.ad 9). By the soul being "in act," Aquinas refers to a soul being present in a human embryo as its first actuality. The soul being "in incomplete act" refers to the fact that a human embryo does not yet exhibit all the soul's powers as second actualities. Aquinas concludes that a soul thus "operates" in a human embryo as its substantial form and in the actual exercise of at least vegetative, and possibly also sensitive, operations; but the soul 
performs "imperfect operations" in that it does not fully exercise all its proper operations until later in its development.

In contrast to a sleeping animal that is sensitive, because it has an active potentiality for sensation, sperm and ovum do not have such an active potentiality. Rather, sperm and ovum are best understood as each having a passive potentiality for being a living, sensitive, rational human being:

[Things] are always in potentiality to actuality when they can be reduced to actuality by their proper active principle with nothing external hindering them. However, seed is not yet such. For it must be by many changes that an animal comes from it. But when by its proper active principle, namely, something actually existing, it can already become such, it is then already in potentiality (In duodecim libros metaphysicorum Aristotelis expositio [In M] IX 6.1837).

The "seed" of a living animal, i.e., a sperm cell or ovum, cannot be said to be a living animal, because it has merely a passive potentiality to become such. The seed must first undergo a change brought about by an extrinsic principle; sperm must be changed through union with an ovum and vice versa, which transforms them into a substance with active potentialities for the definitive operations of a living animal. Whence it can be called a living animal even if it is not actually exercising all its definitive operations.

The change required for something to actualize an active or passive potentiality is brought about by its "proper active principle." An active principle is required because a potentiality can be actualized only by something that is already in a state of actuality. Hence, something can be moved from a state of potentiality to a state of actuality only by some active principle that is either internal or external to it. A sufficient condition for something's having an active potentiality is if it can actualize the potentiality by some active principle internal to it. In his explicit account of embryogenesis, Aquinas does not 
recognize the presence of an active internal principle in an early embryo or fetus which indicates that it has an active potentiality to develop the proper organs required for rational thought. This lack of recognition, though, is due to Aquinas not being aware of how DNA functions in a zygote or early embryo to guide its natural development such that it comes to have the requisite organs. Aquinas postulates a "formative power" (virtus formativa), which is transmitted by the male semen and thereby is extrinsic to a zygote or early embryo, that guides its development (SCG II 89). The contemporary understanding of DNA, however, places this formative power in a zygote or early embryo itself and this fact would arguably motivate Aquinas to define a zygote or early embryo as having an active potentiality for rational operations, since it has an active internal principle guiding it to develop the requisite organs for such operations to occur (Reichlin, 1997; Wade, 1975). ${ }^{11}$

Donceel contends that only a functioning cerebral cortex provides the proper material organization for rational thought and thus is required for there to be sufficient evidence of a fetus's having an active potentiality for such operations. But this contention overlooks the distinction between a natural potentiality and a capacity in hand. It must be noted that, from the moment that the fertilization process is complete, a zygote has a complete human genome and other material factors that are sufficient - given a nutritive uterine environment — for the development of a functioning cerebral cortex. From this fact, one can infer that a zygote or early embryo, before it forms a functioning cerebral cortex, has an active potentiality for rational thought in the sense that it has a natural potentiality to develop a capacity in hand for such operations. 


\section{PASNAU}

Pasnau agrees with Donceel's assessment of Aquinas's view concerning when one can assert that a developing embryo is informed by a rational soul. In addition to the basic Thomistic metaphysical principle that a material body must be properly disposed for the sake of its substantial form, Pasnau contends that DNA functions in much the same way as Aquinas's "formative power" by which a developing embryo is destined to become a human being when it is not yet a human being. Pasnau further argues that a developing embryo, prior to cerebral formation, lacks an active potentiality for rational thought. ${ }^{12}$

In his account of embryogenesis, Aquinas describes the male semen as having a formative power that is responsible for a zygote, and then an early embryo, being formed into an organism with the requisite organs for rational ensoulment:

Therefore, the same power which is divided with the seed, and is called formative, is not the soul, nor does it become the soul in the generative process; but ... it brings about the body's formation insofar as it acts by virtue of the father's soul, to whom generation is attributed as the principle generator, and not by virtue of the conceptus's soul, even after the soul is in it; for the conceptus does not generate itself, but is generated by the father (SCG II 89).

What motivates Aquinas's conclusion here is an attempt to counter the claim that a rational soul is present in the male semen, and that generation occurs through the transmission and separation of the rational soul from the semen once matter-in the form of menstrual blood—is provided by the mother. Aquinas's goal in countering this position is to support his assertion that a rational soul cannot result from any natural reproductive process, but must be directly created by God (QDP III 9; SCG II 86-87; ST Ia 90.2, 118.2; CT 93). Nevertheless, Aquinas recognizes that among the "active 
powers" of semen is a power to form the maternal blood into a new substance, i.e., a living substance, and then to form that living substance into an animal substance, and then to form that animal substance into one that has the proper organs to support rational thought. Aquinas thus postulates a formative power in semen that guides the natural reproductive process, such that the material body which ultimately results from this process is one that is suited for having a rational soul as its substantial form. ${ }^{13}$

Pasnau finds Aquinas's formative power to function in much the same way as DNA: “Just as DNA provides a complete blueprint for the body's development, so the [formative power] contains every feature of the developing body; but contains it 'virtually' or 'potentially' rather than actually" (Pasnau, 2002, p. 103). Pasnau points to a passage in which Aquinas compares the active power of semen to the blueprint for a house in its builder's mind:

The active power which is in the seed, although it is not the soul actually, is nevertheless the soul virtually; just as the form of a house in the soul is not a house actually, but virtually. Hence, just as from the form of a house, which is in the mind, may come the form of a house in matter, so from the seed's power may come a complete soul, except for the intellect which is from outside (In M VII 8.1456).

While the formative power of semen does appear to function in the way DNA is understood to function, Pasnau (2002, p. 104) admits that there are limits to the comparison he makes. A crucial difference is that DNA is present in each cell of a human body and plays an active role in a body's development and functioning well beyond the point of its being informed by a rational soul. The formative power of semen, on the other hand, has a much more limited role in that it guides the development of an embryo to the point of its being properly organized to be informed by a sensitive soul. 
Once an embryo is informed by a sensitive soul, there is no further need of semen's formative power:

After, by virtue of the active principle in the semen, the sensitive soul is produced in the generated thing in one of its principle parts, then the offspring's sensitive soul begins to work towards the completion of its own body through nourishment and growth. But the active power in the semen ceases to exist as the semen is dissolved and the spirit which was in it dies away (ST Ia 118.1.ad 4).

When the sensitive soul's capacity for nourishment and growth become active, the animal embryo guides its own continued development towards rational ensoulment. In what follows, I contend that it is not necessary for Aquinas to draw even this conclusion given the presence of a complete human genome after the formation of a zygote.

Stephen Heaney argues that, given the contemporary understanding of DNA, one can assert that an embryo's mother and father each provide "seed" with a formative power insofar as each provides a gamete with twenty-three chromosomes that contribute to the embryo's genetic identity. Heaney nevertheless thinks it would be misleading to assert that the genetic material of the gametes be considered as the formative power present in the embryo that guides its biological development. Rather, the formative power results from the embryo's own genetic identity which is constituted from, but is not identical to, the genetic contribution of the gametes from which the embryo was formed:

Genetic material from the sperm does not work independently, any more than does that from the mother; it is only when they come together that there is any development in the direction of the maturity of the individual ... Genetic material, being essentially chemical, operates by the same basic properties as any chemical compound: the parts may have one set of characteristics, but, with their joining, they each cease their former existence, and a new set of characteristics becomes manifest ... The ovum carries twenty-three chromosomes, bearing the generative power of the mother; the sperm's twenty-three chromosomes bring the generative 
power of the father. When they meet at fertilization, however, the combination takes on a new set of characteristics specific to this embryo (Heaney, 1992, pp. 30-1).

Pasnau's comparison of semen's formative power and the contemporary understanding of DNA is not compelling. The human genome plays an active role throughout and beyond the embryogenetic process, whereas semen's formative power ceases with sensitive ensoulment. Aquinas is motivated to postulate semen's formative power to counter the argument that a rational soul is somehow present in semen to guide embryonic development. It is not necessary, however, to appeal to semen's formative power to account for the guided development of a human embryo with a complete human genome. As Heaney notes, the genetic contribution of each parents' gametes provides a necessary, though not a sufficient, condition for the formation of a human body suitable to be informed by a rational soul. Since the genetic contribution of sperm alone is not sufficient for the formation of such a body, it is no longer necessary to counter the objection that a rational soul is transmitted by the paternal contribution to human reproduction. Such an objection has no force in the light of contemporary genetic knowledge. Therefore, it is reasonable to interpret Aquinas's metaphysical view in the following way. Instead of postulating a formative power in the paternal gamete, there is a formative power present in the embryo by virtue of its genome which is derived from, but not identical to, that of its parents. It can be further concluded that, instead of an embryo's genome representing a mere formative power, it indicates the presence of a rational soul functioning as the active "blueprint" (Eberl, 2000b, pp. 221 and 223, n. 35) guiding the embryo's development from a human being with an active potentiality for 
rational thought into a human being who actually thinks rationally once the proper organs for sensation and imagination are formed and begin to function.

Pasnau (2002, p. 115) argues that a zygote or early embryo does not have an active potentiality for rational thought by asserting that Aquinas defines an active potentiality as having a capacity in hand to perform some action, and thereby denies that a natural potentiality, as defined above by Kretzmann, is a type of active potentiality. Pasnau utilizes a distinction between an assembled hammer, which has a capacity in hand to drive nails, versus unassembled pieces of metal and wood, which lack a capacity in hand to drive nails. In the first case, no further change is required to the hammer's constitution in order for it actually to drive nails; whereas, in the second case, an external agent must assemble the metal and wood pieces for them to have a capacity in hand to drive nails. Pasnau concludes that a zygote or early embryo is akin to the unassembled parts of a hammer. It has only a passive potentiality to develop into an organism with a capacity in hand for rational thought.

Pasnau is correct in holding that, for Aquinas, if the development of a zygote or early embryo depends upon the assembling powers of some external agent, then it does not have an active internal principle for developing into a being that actually thinks rationally. It thus would have merely a passive potentiality for rational thought and could not be considered as informed by a rational soul. Contemporary genetic understanding, however, indicates that a zygote or early embryo has an active internal principle guiding its development into a being that actually thinks rationally; it has an active potentiality for rational thought in the sense of a natural potentiality. A zygote or early embryo is not akin to the unassembled pieces of a hammer; while such pieces depend upon an external 
agent to assemble them in the proper fashion, a zygote or early embryo has no such need. Given a supportive environment—one that provides simply nutrition, oxygen, and protection from harmful external influences - a zygote or early embryo will develop into a being that has a capacity in hand for rational thought and that actually thinks rationally. That the actualization of this natural potentiality requires time and internal development does not count against its being an active potentiality.

A zygote or early embryo and a hammer differ greatly in that the former is a natural substance, whereas the latter is an artifact. Aquinas's Aristotelian understanding of the distinction between natural substances and artifacts leads to different conclusions regarding what is required to assert the presence of an active potentiality in each type of thing. Pasnau correctly understands Aquinas's criterion for an artifact to have an active potentiality for performing its proper function and thus being the type of artifact it is. An assembled hammer requires no further change in its constitution to actualize its potentiality to drive nails; it thus has the definitive capacity of a hammer as an active potentiality, and thereby is a hammer. The unassembled pieces of a hammer, however, require change in their constitution brought about by an external agent before being able to actualize the definitive capacity of a hammer, and thus are not yet a hammer.

For a natural substance, though, its ordered natural development, the principle of which is active and internal to it, is sufficient for it to be that towards which it is developing. Though I have not found an explicit statement by Aquinas on this point, it is likely he would follow Aristotle, who concludes in De generatione animalium:

When we are dealing with definite and ordered products of nature, we must not say each is of a certain quality because it becomes so, but rather that they become so and so because they are so and so, for the process of 
becoming attends upon being and is for the sake of being, not vice versa (DGA V 1, 778b2-6, trans. Platt; see Reichlin, 1997, p. 15).

A key difference between a natural substance and an artifact is the location of their respective formal causes. When a builder is building a house, the formal cause of the house is the idea the builder has in her mind of how the house should appear, i.e., what structure it is to have, once completed. Perhaps this idea has been materially instantiated in a blueprint. Once the house is completed to the builder's satisfaction, in accord with the mental or printed blueprint, the formal cause is now located in the house itself. The matter, having been assembled in the proper fashion, has taken on the form of the house which had previously been found only in the blueprint. Thus, the form of the house is not present in the matter constituting it until the building process is complete.

For a natural substance, however, there is no analogue to the builder in whose mind the formal cause of the substance is located — putting aside the possibility that God acts as such a builder. Rather, the formal cause must be located in the natural substance itself as it is developing towards its final appearance and structure. Its blueprint is internal to it in a way that a house's blueprint is not, since the latter has an external efficient cause that brings it from being potentially a house to being actually a house. A natural substance, which has an internal efficient cause of its development, must be guided in its development by the formal cause already instantiated in it as it moves from being, for example, a human being with the potential for rational thought to a human being who actually thinks rationally after having developed the requisite organic structure. A human being's proper form is thus present in the matter constituting her from the moment her development begins. 


\section{CONCLUSION}

I conclude that the interpretations offered by Donceel and Pasnau, while they closely follow what Aquinas explicitly says concerning embryogenesis, do not correctly take account of the role Aquinas's nuanced concept of "active potentiality" plays in defining the nature of a zygote or early embryo in the light of contemporary genetic understanding. Evidence that a zygote or early embryo has an active internal principle guiding its ordered natural development into a being that actually thinks rationally is sufficient, I contend, to conclude that it is already a rational being. It has an active potentiality for rational thought and is thus informed by a rational soul. I have consistently referred to "a zygote or early embryo," because a contentious issue among interpreters of Aquinas concerns whether a one-celled zygote - the immediate product of conception—or an early embryo—-formed approximately two weeks after conception— should be properly understood as informed by a rational soul (Eberl, 2000a; Ford 1988). Nonetheless, my purpose here has been to show that, by Thomistic standards, rational ensoulment must be prior in embryonic development to the stage argued for by Donceel and Pasnau. ${ }^{14}$

\section{NOTES}

${ }^{1}$ The thesis of reductive physicalism is that human nature is nothing other than what empirical science is able to report it as. The term "reductive" refers to the contention that human nature is nothing over and above the biological and neurophysiological facts which are subject to scientific investigation. On this construal of human nature, all the physical and psychological states of a human being can be wholly explained in virtue of the physical properties of her body. 
${ }^{2}$ Since Aquinas holds that all human beings are persons, I will utilize the terms "human being" and "person" interchangeably.

${ }^{3}$ As a substantial form, a human rational soul is responsible for (1) the existence of a human being, (2) the actualization of the matter composing a human being, and (3) the unity of existence and activity in a human being (SCG II 68; In DA II 2).

${ }^{4}$ This is Aquinas's definition of "person," which applies to, among others types of beings, a body informed by a rational soul (ST Ia 29.1). All translations of Aquinas's text are my own. This definition of "person" was originally formulated by Boethius (Contra Eutychen et Nestorium III).

${ }^{5}$ Following Aristotle (DA II 3, 414a29-415a13), Aquinas defines a "rational" soul as having the relevant capacities for life, sensation, and rational thought and is the type of soul proper to the human species. A "sensitive" soul, on the other hand, has the relevant capacities for only life and sensation, and is the type of soul proper to all non-human species of the animal genus. A "vegetative" soul has the relevant capacities for only life and is proper to all non-animal living organisms.

${ }^{6}$ Since, according to Aquinas, rational operations do not require the use of a bodily organ (QDA II), the requisite organic complexity here is that which allows for the operations of sensation and imagination such that the mind can abstract intelligible forms from phantasms.

${ }^{7}$ Aquinas contends, following Aristotle, that a developing embryo is first informed by a rational soul 40 days after conception if it is male and 90 days after conception if it is female (Scriptum super sententiis magistri Petri Lombardi III 3.v.2). 
${ }^{8}$ Unlike vegetative and sensitive souls, which naturally inform properly organized matter, Aquinas holds that the rational soul of each human being is created directly by God (QDP III 9; SCG II 86-87; ST Ia 90.2, 118.2; CT 93). Nevertheless, he also holds that God does not create a rational soul unless an appropriate body exists for it to inform. For a rational soul has its natural perfection only insofar as it informs such a body to constitute a human being (ST Ia 90.4).

${ }^{9}$ Aquinas's claim that a rational soul includes sensitive and vegetative capacities, and that the sensitive and vegetative souls that had previously informed a developing embryo are annihilated once a rational soul is created, is intended to counter the claim that there are three souls — vegetative, sensitive, and rational — existing at the same time in a fully developed human being. I will not address this debate among Aquinas and his contemporaries here.

${ }^{10}$ While Aquinas would deny identifying or reducing rational operations to physical processes, a rational soul's being united to a physical body as its substantial form allows for a correlation of the two such that one does not naturally occur without the other (Eberl, 2004; LaRock, 2001).

${ }^{11}$ What I have just contended may sound as if I am concluding that an embryo's genetic identity is sufficient evidence of its having an active potentiality for rational thought and thus being a person. I do not, however, hold genetic identity to be sufficient evidence of an embryo's being a person. Donceel (1970, p. 96) rightly notes that, if such were the case, then hydatidiform moles - masses of placental tissue with the same genetic identity as an embryo-would also count as persons. Hence, it is not the case that possessing human DNA is sufficient for something to be a person. What separates hydatidiform 
moles and developing embryos is that the former can never-despite their intrinsic genetic structure and even if they are placed in a supportive uterine environmentdevelop into an organism with a functioning cerebral cortex; the latter can.

${ }^{12}$ For further discussion of Pasnau's view, see Haldane and Lee (2003a) and the subsequent responses by Pasnau (2003) and Haldane and Lee (2003b).

${ }^{13}$ Another motivation for Aquinas's postulation of semen's formative power is to provide a means by which Original Sin is transmitted from parent to offspring (CT 218).

Aquinas, though, does not require semen's formative power for this purpose, because the specifically "human" genome transmitted by both parents in their gametes could be substituted as the medium by which Original Sin is transmitted.

${ }^{14}$ I am most grateful to Eleonore Stump, John Kavanaugh, S.J., Theodore Vitali, C.P., Michael Burke, and a referee of this journal for helpful comments and suggestions on previous drafts of this article. This article was written while I was visiting the Center for Philosophy of Religion at the University of Notre Dame and I thank Alvin Plantinga, Thomas Flint, and Michael Rea for making the Center's resources available to me, as well as Saint Louis University for awarding me a fellowship to fund my visit there during the 2002-03 academic year. 